whether limited monarchy, aristocracy, or democracy, in much the same dissatisfied and despairing tone in which the Preacher of old did. But he concludes his book with drawing comfort from a source which his predecessor of old pronounced impossible. He says :-

"There is yet one branch of human progress which we may contemplate with umixed satisfaction, and that is, the progress of science, both in its discoveries and its adaptations to the convenience and civilisation of mankind. It may be hoped that the acquisitions of science may become an enduring benefit to the world, not to be again obliterated and lost amid the political convulsions to which society may be subjected.

"To this progress the scientific men of every country may contribute, whetber they live under a despotism or under a constitutional government. The pursuit of truth for its own sake is the noblest occupation of the human mind, and from this pursuit it seems proboble that mankind will reap the richest reward."

A fairer comment fr ma mo:e qualified and disinterested writer was never made upon the motto of this journal-

$$
\text { "To the solid ground }
$$

Of Nature trusts the mind which builds for aye."

W. $O$.

\section{Scientific Jokes}

You can hardly expect all your readers to see through the jokes at p. 337 of your last number. I instance only two out of many.

"The energy of heat is made up of heat and temperature" ! This may set some earnest but i nnorant students to find how Joule's Equivalent depends on temperature : and it would be well to warn them.

"Profs. Ayrton and Perry have developed a theory of terrestrial magnetism . . . which coincides well with facts." Here the reader should have been told that Rowland has proved that, according to this theory, the moon would have been repelled into the profundity of space, and the greater part of the earth's surface, including its atmosphere, torn off by the enormous electric forces involved.

G. H.

\section{Stags' Horns}

CONCERNING the disappearance of cast horns, the theory that stags retire to secluded spots, about the time for shedding their horns, mentioned by B. W. Barton in NATuRE, vol, xxi.p. 325, may be perfectly correct where the animals have woods to go to, but this opinion cannot hold good with the thousands of reindeer that frequent the barren lands of the north-east part of America; yet it is rare to find on these "barrens" the shed horn of either buck or doe, although the latter drop their horns in May or June, when at or on their way to their far north summer quarters.

As far as I have observed, the new horns of the male reindeer (in the wild state) do not begin to grow until weeks after the old ones have dropped off, and there is no danger of one stag "disturbing" another, when all have their horns in the tender velvety stage; in fact, no animals can be less pugnacious than these fine creatures are during eight months of the year.

2, Addison Gardens, South Kensington, Feb. 7 J. RAE

Apropos of the question of stags' horns, I have just come upon the following in Miss Bird's "Life in the Rocky Mountains."

Describing the so-called "Parks" of the Rocky Mountains as "bigh-lying valleys large and small, at heights varying from 6,000 to II, cos feet," she says, "Parks innumerable are scattered throughout the mountains. . . They always lie far within the Foot Hills. . . Hundreds can only be reached by riding in the bed of a stream, or by scrambling up some narrow cañon till it debouches on the fairy-like stretch above. These parks are the feeding-grounds of innumerable wild animals, and some, like one three miles off, seem chosen for the process of antlercasting, the grass being covered for at least a square mi'e with the magnificent branching horns of the elk." P. I22. B. W. S.

\section{"Song of the Screw"}

Frof. TAIT has inadvertently attributed to the late lamented Prof. Clerk Maxwell (NATURE, vol, xxi. p, 32I) an effusion of mine consisting of a synopsis of Dr. Ball's Treatise on Screws, which appeared in NATURE, vol, xiv. p. 30 , under the above title.
As a very humble poet, the occurrence of such a mistake has satisfied my highest ambition; and I feel like a second Chatterton. J. D. EVERETT

\section{The Post Office and the Telephone}

PRAY allow me to correct an important misprint which has occurred in the last paragraph of the abstract of my address which you were good enough to insert in your last number. I said that the Post Office did not wish to restrict or in any way to interfere with the use of the telephone; our only object was to prevent the establishment of a particular branch of Post Office telegraph business without, not with, its licence or consent. General Post Office, February 9

W. H. PREECE

\section{KARL VON SEEBACH}

CEOLOGISTS will learn with universal regret of the death, after a painful illness, of the distinguished Professor of Geology at Göttingen, Karl von Seebach. Although Prof. von Seebach was still a young man at the time of his death, he had already made his mark in science, and his career promised a distinguished future. Von Seebach's earliest studies were devoted to stratigraphical geology and palæontology, and he devoted much time to the preparation of a geological map of the kingdom of Hanover, and to his earnest labours much of the excellence of this map is due. The result of Prof. von Seebach's studies of the stratified rocks of Hanover are embodied in a number of separate memoirs and in his well known treatise "Die Hannoverischer Jura."

During his later years Karl von Seebach's studies were devoted to wider questions, and the investigation of volcanic phenomena occupied his attention. He visited the island of Santorin and wrote an important work on the eruption of 1866 . He also published several interesting memoirs on the volcanoes of Central America, a district which he visited in 1865 . Geological science has sustained a heavy loss by his early death.

\section{ARTHUR JULES MORIN}

THE serious illness of General Morin to which we alluded in our last number, was followed by his death at Paris on Saturday, February 7 , in his eighty-fifth year. Arthur Jules Morin was born at Paris, October 17, 1795. He entered at an early age the famous Ecole Polytechnique, but was summoned from his studies during the fatal campaign of 1814 to assist in the defence of Paris, and rendered good service in the brigade of artillery. At the conclusion of peace he devoted four years to practical studies in military engineering at the École d'Application of Metz, and entered the army as lieutenant in a pontoon regiment. His military career was marked by a rapid and regular promotion through the different grades, terminating in his appointment as an Artillery General of Division in 1855 .

General Morin's reputation rests however chiefly on his achievements in the peaceful departments of physical research, as well as on unusual executive abilities in the same connection. As an investigator his attention was directed almost entirely to the solution of problems in mechanics. In a remarkable series of memoirs presented to the Academy at Paris, during the years I833-1835, Morin gave the results of exhaustive experiments on friction, and established the three general laws of this part of mechanics, viz. :-Friction is proportional to the pressure exerted by a body on the supporting surface depends on the nature and smoothness of the surfaces in contact, but not on their superficies; and is independent of the rapidity of the motion. Equally well-known is his ingenious apparatus for determining the laws of falling bodies, in which a pencil attached to a falling -weight, describes a curve on a perpendicular cylinder, rotating alongside the path of the descending body. The parabolic curve obtained by this simple but exact contrivance, 